\title{
Exploring Hawaiian long-term insular geodiversity dynamics
}

\author{
Arie C. Seijmonsbergen ${ }^{1}$, Jorinde Guldenaar², Kenneth F. Rijsdijk ${ }^{1}$ \\ 'Institute for Biodiversity and Ecosystem Dynamics, Universiteit van Amsterdam, The Netherlands; a.c.seijmonsbergen@uva.nl \\ ${ }^{2}$ Sustainability, Management and Innovation, Vrije Universiteit van Amsterdam, The Netherlands
}

\begin{abstract}
The role of time is underrepresented in assessments of geodiversity. Hot spot islands are unique systems to explore long-term geodiversity dynamics. The geodiversity dynamics of seven Hawaiian Islands are analysed by a qualitative-quantitative assessment using a geodiversity index. As input, freely available geological, soil and hydrological datasets are used, along with topographic diversity variables calculated from a digital elevation model. Long-term geodiversity dynamics were evaluated through correlation of island age to geodiversity class and assessment of the role of each contributing variable to the geodiversity class. The results indicate that high geodiversity is positively correlated with increasing island age, while younger islands generally correlate with low geodiversity classes. This is explained by the high contribution of topographic variables, and to a lesser extent by hydrological development and soil formation over time. These findings suggest that geodiversity dynamics play an important role in the life cycle of hot spot islands.

Keywords: geodiversity dynamics, island ontogeny, topographic attributes, natural diversity, Hawaiian Islands
\end{abstract}

\section{Introduction}

The mapping and interpretation of geodiversity patterns is a novel field in scientific and applied research. Geodiversity as a discipline is increasingly being included in the assessment and management of natural and cultural environments (Zwoliński et al. 2017). It is also being used as an instrument to value ecosystems and its services and to explain biodiversity distribution (Hjort et al. 2015, Bailey et al. 2017, Tukiainen et al. 2017). However, in most geodiversity studies, temporal aspects of geodiversity are underrepresented. Such assessments are complex, not only due to the absence of efficient temporal analyses methods, but also due to the absence of comparable data, especially over long timescales (Zwoliński et al. 2017).

Geodiversity dynamics is not explicitly mentioned in the widely used definition of Gray (2013): the natural range (diversity) of geological (rocks, minerals, fossils), geomorphological (land form, processes) and soil features. It includes their assemblages, relationships, properties, interpretations and systems. Still, the key components of this definition can be used to quantify geodiversity dynamics with references to existing workflows. Today, many qualitative-quantitative studies on geodiversity are based on spatial data collected from expert-based geological, geomorphological, hydrological and soil inventories (Zwoliński et al. 2017). Traditionally, time relations are common concepts in these disciplines, for instance chronostratigraphy in geology, landform evolution in geomorphology and development of soil types into catenary chronosequences. However, in geodiversity assessments, such temporal aspects are scarce and hardly developed. This is probably related to the broad purposes and applications of most geodiversity studies, and because geodiversity is still going through a process of conceptual self-affirmation (Araujo and Pereira 2017).

Broadly, geodiversity and its quantification have their roots in geoconservation and scientific applications (Gray 2013, Zwoliński et al. 2017), with a focus on geoheritage and geotourism (Zwoliński and Stachowiak 2012, Knight et al. 2015, Newsome and Dowling 2017), nature conservation (Burek and Prosser 2008, Pellitero et al. 2011), and land management (Pereira et al. 2013, Seijmonsbergen et al. 2014, Pellitero et al. 2015, Silva et al. 2015, Najwer et al. 2016, Araujo and Pereira 2017). More recently, (com- 
ponents of) geodiversity have been used to explain the distribution of biodiversity resulting from landscape patterns (Hjort et al. 2015, Bailey et al. 2017).
Geodiversity mapping and assessment methods can be grouped according to their data collection source into direct (field-based) and indirect (data-driven)
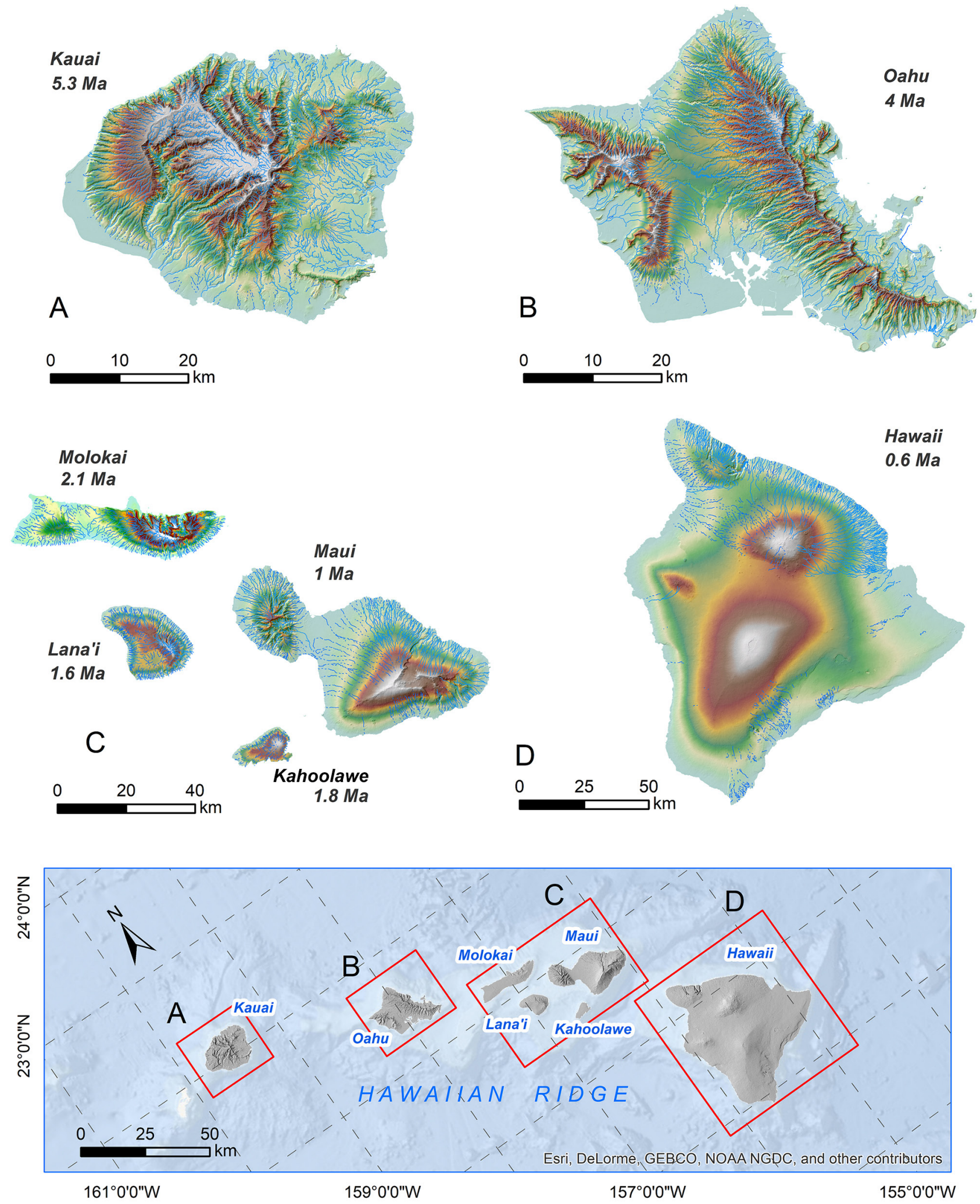

Fig. 1. Location map of the seven Hawaiian Islands (lower panel). Upper panel A-D illustrate details on the topographical variation and hydrological variation in surface drainage within and across the islands. Island ages are taken from Eckstut et al. (2011) 
methods (Pellitero et al. 2015), while the procedure recognizes qualitative, quantitative and combined qualitative-quantitative methods (Zwoliński et al. 2017). Quantitative methods include geodiversity indices (GDIs), that calculate the variety in a predefined grid or unit (Serrano and Ruiz-Flaño 2007, Araujo and Pereira 2017, Melelli et al. 2017), or use a weighting and ranking scoring system (Zwoliński and Stachowiak 2012, Pereira et al. 2013) to assess a value of geodiversity. Pellitero et al. (2015) and Zwoliński et al. (2017) provide a more complete overview of geodiversity research and assessment methods. General instruments to map, quantify and compare geodiversity across landscapes are still in development, especially at global scales (Zwoliński et al. 2017). The introduction of a temporal factor in geodiversity assessments, requires that alignment of methods to demonstrate its operationalization should be made, for instance with respect to the selection of suitable mapping scales, study area extent and grid sizes. In general, quantitative information on local geodiversity and its dynamics is scarce.

Hotspot archipelagos are ideal study systems to explore the role of time in geodiversity development, due to the often linear age progression of volcanic islands and comparable geological build-up of the islands. The hot spot islands of the Hawaiian archipelago are located in the Pacific Ocean (Fig. 1). They chronologically increase in age away from the hotspot, which allows the role of time on geodiversity dynamics to be assessed. A preliminary model that describes the dynamics of volcanic islands over their existence was first recognized by Charles Darwin (1842), who related atoll formation as a final stage in the life cycle of a volcanic island. Wilson (1963) was the first to relate the dynamics of volcanic island evolution to a mobile crust and mantle plumes, a foundation paper for plate tectonics as showcased in the Hawaiian Islands. This cyclic model of life cycles of volcanic islands over time has become a template for volcanic island evolution globally and has recently been acknowledged as ontogenic cycles of volcanic islands by biogeographers (Stuessy 2007, Whittaker et al. 2008), an analogy to the ontogeny of organisms that describe their stages of development from embryo to adult. Many researchers have, since then, used the ontogeny of islands in a general dynamic model (GDM) theory to explain patterns in biodiversity seen on the islands differing in age and stage in the ontogenic cycle (Whittaker et al. 2017). While these hypotheses seem to successfully explain elements of the spatial and temporal distribution of biodiversity on islands (MacArthur and Wilson 1967, Warren et al. 2015, Whittaker et al. 2017), they do not explicitly address (components of) geodiversity and its dynamics. To illustrate the importance, the complex interactions and co-evolution of topogra- phy and hydrology on the evolution of oceanic island landscapes has been reviewed in a study by Jefferson et al. (2014), who concluded that dissection of volcanic landscapes typically begins $0.5-2 \mathrm{Ma}$ after eruption of the last lavas that form the main shield.

In this paper, we aim to assess the role of time in geodiversity and to explore the long-term effects of the geological evolution of seven Hawaiian hotspot islands on geodiversity dynamics, based on an indirect index-based approach, using freely available datasets.

\section{Evolution of the Hawaiian archipelago}

The entire Hawaiian archipelago comprises of more than a hundred islands spread over $2400 \mathrm{~km}^{2}$, and evolved under comparable geo-tectonic conditions above a mantle plume in the Pacific Ocean (Clague and Dalrymple 1989). The age of the Hawaiian Islands (Fig. 1) is well-known (Clague and Dalrymple 1989, Eckstut et al. 2011) and is related to phases of accretion, maximum growth and degradation (Wilson 1963). The eight main islands at the southern end of the archipelago arose sequentially over a period of more than five million years, during which a unique biodiversity developed, in tandem with the volcanic islands geodynamics (Ziegler 2002, Stuessy 2007, Roderick et al. 2012, Whittaker et al. 2017). In the general dynamic theory in biogeography it is argued that a peak in biodiversity coincides with a peak in elevation (Stuessy 2007, Whittaker et al. 2017) or topographic complexity (Whittaker et al. 2008) attained during the final stage of connection of the volcanic edifices to the mantle plume. Subtle modifications of the model include the effect of low-frequency mega landslide events on topographic complexity of the Hawaiian Islands and the long-term effect of island subsidence (Whittaker et al. 2008, 2017). Mega landslides or 'flank collapses' may cause large scars in volcanic islands over relatively short time periods. Those landslide scars reshape the previously existing topography, and create, at the same time, new habitats for flora and fauna. Such low-frequency mega-landslide scars can, in most cases, still be observed in the general geomorphological structure of volcanic islands. The effect on the landscape also sets back time-related processes such as weathering, soil formation, fluvial incisions and therefore, general geomorphological landscape development. In the accretion phase, active volcanic islands develop on top of the oceanic crust and grow in elevation, and often emerge above sea level as shield volcanoes, which are characterized by relatively low-angle slopes (Jefferson et al. 2014). Elevation increases with magmatic additions until the mantle plume is disconnected 
A

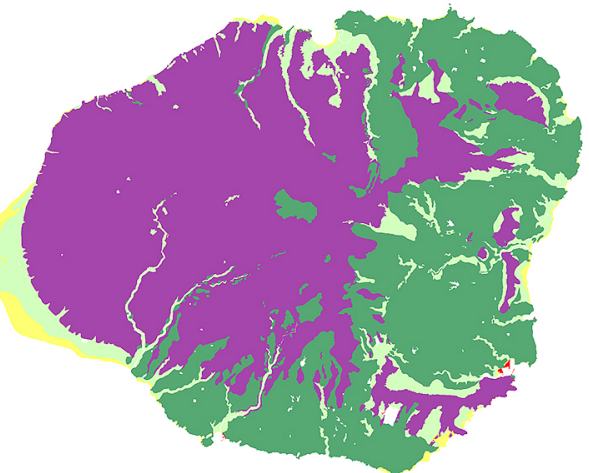

$\begin{array}{lll}0 & 10 & 20\end{array}$
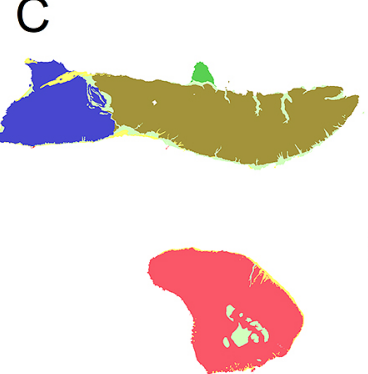

0
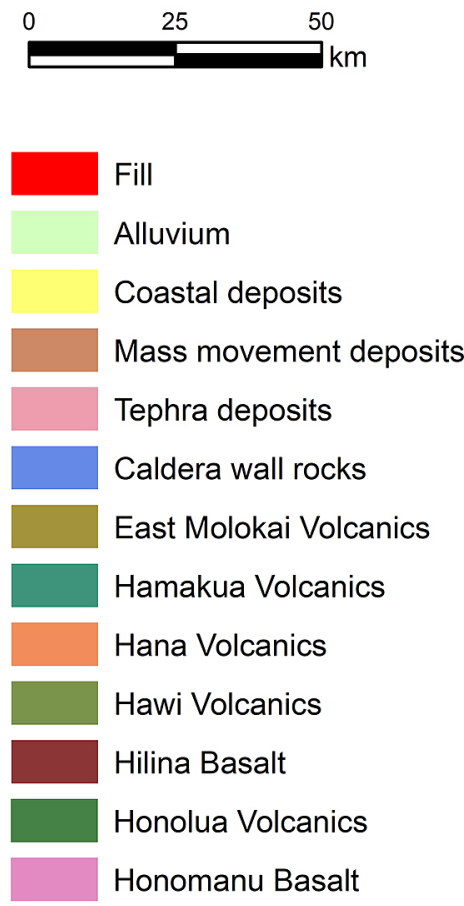

B

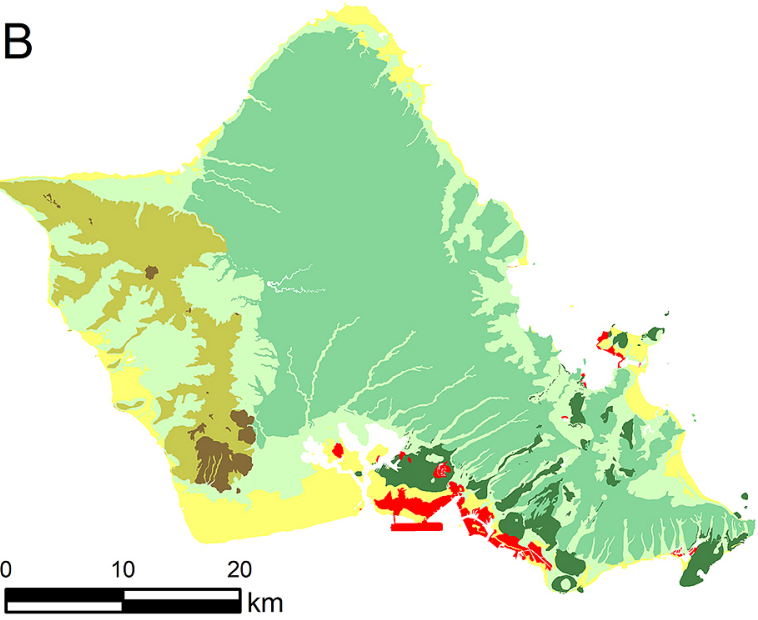

D



Hualalai Volcanics

Kahuku Basalt

Kalaupapa Volcanics

Kanapou Volcanics

Kau Basalt

Kiekie Volcanics

Kolekole Volcanics

Koloa Volcanics

Koolau Basalt

Kula Volcanics

Young volcanic rocks of Kahoolawe

Lahaina Volcanics

Lanai Basalt

Fig. 2. Geological maps of the Hawaiian islands (after Sherrod et al. 2007) 
from the island's active volcanoes, after which island development is overtaken by exogenic processes. The short-lived geomorphological (e.g. fluvial dissection, mass movements, wave action) processes can then modify local and regional geodiversity of the landscape. The mineralogical and petrographic composition between the islands on a stable mantle plume will not drastically change over time, therefore it is more likely that the geomorphodiversity, in our study reflected in the topographical diversity, will be more decisive for changes in temporal geodiversity.

\section{Hawaiian geodiversity}

The geodiversity dynamics of the Hawaiian Islands have not been assessed in the light of island ontogeny, although all Hawaiian Islands are known for their outstanding natural beauty and diversity, and their amazing volcanic geological and geomorphological features, which is reflected in the presence of a variety of conservation areas, e.g. World Heritage Sites, National Parks, National Monuments and Historic Sites (NPS 2017). Information on the geological, soil, hydrological and topographical diversity can be collected from available maps and literature.

\section{Geological diversity}

The geological history of the Hawaiian Islands and their lithological composition is well understood (Clague and Dalrymple 1989, Ribe and Christensen 1999) and documented in detailed geological maps (Sherrod et al. 2007). The majority of the rocks are basaltic lava flows, scoria, ash and tephra deposits, which have been aggregated into local formation names on the various islands (Fig. 2), such as West and East Molokai Volcanics (lava flows, vent deposits, domes), Hualalai Volcanics (lava flows, spatter or tuff cones) and Hana Volcanics (lava flows, tephra, cinder and spatter, ash poorly to non-indurated). Other units suggest homogeneous rock types such as the Kau and Puna Basalt (Hawaii), but include subunits such as lava flows, spatter or tuff cones and littoral deposits. Although variations in chemical composition exist, the volcanic materials in the Hawaiian archipelago are rather homogeneous. Therefore, different formation names often reflect comparable rock types across the islands. This is also the case for the occurrence of recent geological materials that originate from landslides, littoral deposition, and other fine scale processes. These Quaternary units are mostly small in area and include Younger and Older Alluvium, Beach deposits, Kaupo Mud Flow, Lacustrine deposits, Lagoon deposits, Lagoon and Reef deposits, Landslide deposits, Marine conglomerate and breccia, Older and Younger Dune deposits and talus and colluvium. On the geological map (Fig. 2) these are relatively small units that are combined into Alluvium, Coastal deposits and Mass movement deposits. The original units however, have been used in the analysis of the geodiversity.

\section{Soil diversity}

The Hawaiian Islands show large diversity in soil types over small distances (Fig. 3). This is reflected in the presence of 11 soil orders (classified by the US system) on the 1:250,000 scale soil map of the Hawaiian Islands, which will be described briefly (USDA 2015, Table 1). Andisols are weakly to more strongly weathered soils generally formed in volcanic ash and tend to be highly productive. Aridisols show little soil development due to the lack of moisture availability and often accumulate crusts. Entisols develop in areas of dynamic processes or in areas where erosion or deposition rates are faster than the rates of soil development. Histosols are soils that have a high organic content, such as bogs and peat, mostly developed a stagnant, moist environment. Inceptisols occur in both semiarid to human environments which are characterized by moderate weathering and a wide range of soil properties. Mollisols are soils that have a dark coloured surface and are generally base-rich and fertile. They develop in climates with a moderate to pronounced moisture deficit. Oxisols are highly weathered soils of low fertility in tropical and subtropical regions that mainly occur in stable

Table 1. Metadata of the datasets

\begin{tabular}{|c|c|c|c|c|c|c|}
\hline Sub-index & Description & Data type & Coordinate system & Scale/cell size & Publication date & Source \\
\hline Geology & Geological units & Polygon & NAD83_HARN_UTM_zone_4N & $1: 250,000$ & 2007 & USGS \\
\hline Pedology & Soil units & Polygon & GCS_WGS_1984 & $1: 250,000$ & 2015 & USDA \\
\hline DEM & Surface elevation & Raster & NAD83_HARN_UTM_zone_4N & $10 \times 10 \mathrm{~m}$ & 2007 & $\begin{array}{l}\text { NOS \& } \\
\text { NCOSS }\end{array}$ \\
\hline Hydrology & $\begin{array}{c}\text { Perennial, } \\
\text { non-perennial } \\
\text { streams }\end{array}$ & Line & GCS_WGS_1984 & $1: 24,000$ & 2010 & USGS \\
\hline Hydrology & $\begin{array}{l}\text { Lakes, ponds, } \\
\text { reservoirs }\end{array}$ & Polygon & GCS_WGS_1984 & $1: 24,000$ & 2010 & USGS \\
\hline
\end{tabular}


areas. Spodosols tend to be acid, non-fertile soils that are characterized by leaching from e.g. aluminum which is deposited in the subsurface. Ultisols are acid soils developed in humid areas under fairly intense weathering and leaching processes, resulting in a clay-enriched subsoil dominated by quartz, kaolinite and iron oxide minerals. Vertisols have a high content of expanding clay minerals, restricted leaching and relatively high fertility. Lava Flows, Water and No Soil Data, of which the latter comprises $3.5 \%$ of the area are added units to the commonly recognized units. The spatial arrangement of soil orders results from differences in the main soils forming factors, climate, topography, biota, parent material and time

A



0

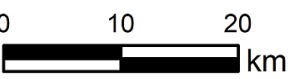

\section{C}

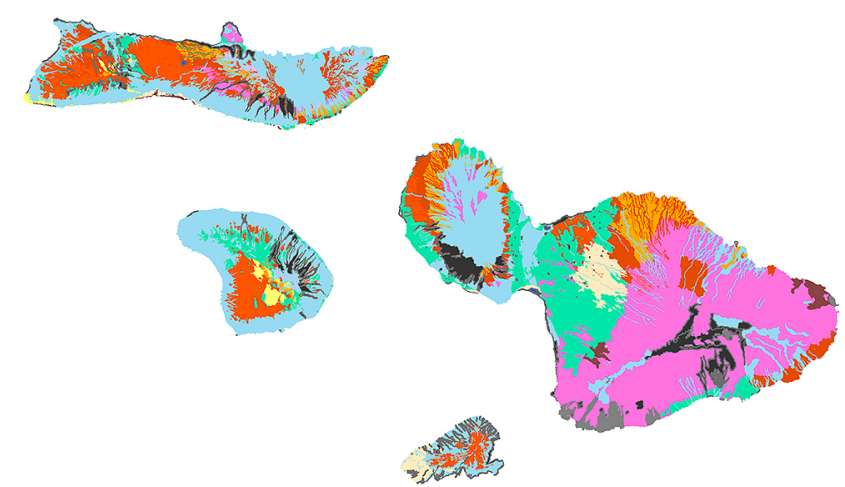

(Jenny 1994). The added value of including soil distribution data into the geodiversity index is that soil boundaries do not always reflect the composition of the underlying geological parent material. Histosols are examples of accumulation of organic-rich material which is unrelated to most substrata. Soil forming processes, such as leaching, illuviation, oxidation and reduction generate chemically different soil horizons and thus soil units over time. As such, soils contribute in a unique manner to geodiversity. The current spatial distribution and diversity of the various soil types on the islands also relates to the fragmentation of the landscape into smaller units, due to soil erosion and fluvial dissection. In general, younger soils

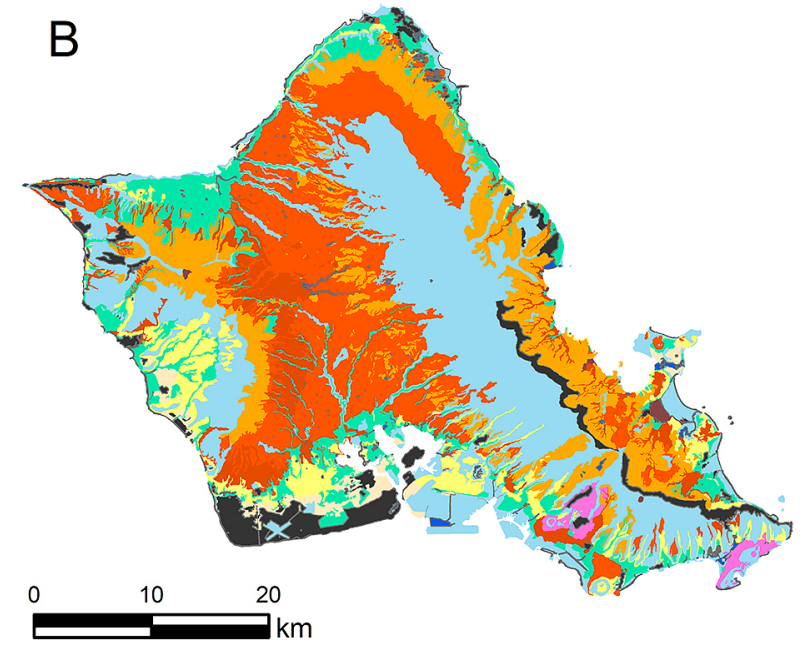

D



0 25 50 $\mathrm{km}$ Soil Order

\begin{tabular}{|c|c|c|c|}
\hline Andisols & Histosols & Oxisols & Vertisols \\
\hline Aridisols & Inceptisols & Spodosols & Lava flow \\
\hline Entisols & Mollisols & Ultisols & Water \\
\hline
\end{tabular}

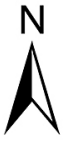

Fig. 3. Soil maps of the Hawaiian Islands (after USDA 2015) 
such as Andisols and Entisols, occur more frequent and in larger extents on the younger islands, while the more ripened soils, such as Oxisols, Ultisols, Spodosols and Vertisols occur more frequently on the older islands (Fig. 3). Ibáñez and Effland (2011) found that soil richness and age are strongly correlated for the higher hierarchical level of the USDA Soil Taxonomy (Orders, Suborders and Great Groups) for the Hawaiian archipelago and that soil patterns could be explained by the influence of plate tectonics via relief, area and perhaps island age.

\section{Hydrological diversity}

The hydrological diversity of the Hawaiian Islands (USGS 2010) is strongly correlated to (seasonal) rainfall patterns and elevation diversity, which promotes differences in presence and densities of perennial and intermittent streams within islands. On all islands, radial and parallel drainage patterns developed, as the result of volcanic eruption centres. On the older islands dendritic drainage patterns developed locally, and rivers may already show meandering because evolution of the surface hydrology was no longer hampered by active volcanism, which prohibits drainage development. Such controls on the hydrological and topographic evolution of shield volcanoes and volcanic ocean islands were studied by Jefferson et al. (2014), who concluded that topographical younger islands such as the typical shield volcano topography of Hawaii, have higher elevation and area, but have lower mean slope angle values. The spatial distribution of surface hydrology is presented in the location map (Fig. 1). Trade winds in combination with the orientation and elevation of the islands leads to unequal distribution of rainfall. This influences the river density especially on Hawaii Island (Fig. 1), which has a wet north-eastern part and a dry southwestern part. On lower and older islands this effect is less prominent. In addition, a clear distinction between perennial and non-perennial rivers is seen on Hawaii and Maui (and to lesser extent on the other islands), which is attributed to seasonal rainfall effects as well.

\section{Topographical diversity}

The topographic diversity of the islands is generally high, across and within the islands (Fig.1). The youngest of the seven islands, Hawaii (referred to as the Big Island, 0.6 Ma), is known for its active volcanism and assumed to be close to maximum growth (Mauna Kea at 4,207 $\mathrm{m}$ a.s.l. and Mauna Loa at 4,169 m a.s.l.), while the older islands are beyond maximum growth (Fig. 1). For example, the island of Kauai (5.3 Ma), has a lower maximum elevation (1,598 $\mathrm{m}$ a.s.l.), but its surface is characterized by higher internal varia- tions in elevation and slope range relative to Hawaii. This means that the older Hawaiian islands, disconnected from the mantle plume, typically developed larger variations in elevation range (a measure of the amplitude of internal relief), which is expressed in higher slope angles and variation of elevation within a certain distance. The islands of Maui, Lanai and Molokai do differ in age, but were connected as one, bigger island during the lower sea levels of Pleistocene glaciations. This implies that individual islands or island groups may experience changes in surface area under different sea water levels (Rijsdijk et al. 2014).

\section{Data and Methods}

The workflow (Fig. 4) has three distinct phases: pre-processing, analysis and deliverables (results). The workflow generally follows the procedures proposed by Pellitero et al. (2015) and Najwer et al. (2016), while keeping in mind the purpose and scope of this study. Important steps were the acquisition and selection of freely available data from existing databases, the development of environment-specific geodiversity assessment indices, the computation of



Fig. 4. General workflow for exploring insular geodiversity dynamics of the Hawaiian Islands 
topographical attributes, the selection of an effective GDI, and the reclassification and conversion into final geodiversity maps. After that, the resulting classifications and statistics across islands of different ages were visualized and evaluated in the light of geodiversity dynamics.

\section{Pre-processing}

In the pre-processing phase thematic maps and a digital elevation model (DEM) were collected from freely available sources (Table 1). Data pre-processing was done in ArcMap 10.4 to geographically align the datasets, rasterize all vector data at $10 \mathrm{~m}$ cell size, create a suitable analysis grid, select the appropriate attributes and calculate DEM-derived topographic attributes. The digital geological maps of the Hawaiian Islands originated from various sources and were compiled at 1:250,000 scale by Sherrod et al. (2007).

To prevent too much detail in lithological and age variation, fifty geological units (Fig. 2), described in the geological diversity section, were selected for the calculation of the geology diversity (Gdi). The soil maps (Fig. 3) which are described in the soil diversity section, were derived from the United States Department of Agriculture (USDA 2015) and processed using soil order as input data for calculating the pedology diversity (Pdi). The hydrology diversity (Hdi) was based on the occurrence of perennial and intermittent rivers (Fig. 1) and a dataset of waterbodies (USGS 2010). The topographic diversity (Tdi) was based on a $10 \mathrm{~m}$ DEM of the Hawaiian Islands (Greenberg 2007), which was pre-processed to calculate range and standard deviations of elevation and slope as variables. According to Hengl (2006), the choice of an optimal working grid should be a compromise between the coarsest and finest legible grid resolution with respect to the original scale of work and properties of a dataset, spatial objects and topography. For selection of the optimal resolution, the following formula was used (Hengl 2006) for calculating the coarsest grid resolution: $p \leq S N \times 0.0025$, where $p=$ grid resolution and $S N=$ scale number. The finest legible grid resolution was $p \geq S N \times 0.0001$, while the recommended grid resolution is a compromise between the smallest and largest grid size: $p=S N \times 0.0005$. In this study, using 250,000 as $S N$, the coarsest grid size would be 625 $\mathrm{m}$, the finest grid size $25 \mathrm{~m}$, and the recommended grid size $125 \mathrm{~m}$. Since accuracy data for the thematic maps were not available and the soil maps contained $3.5 \%$ no data areas, we decided to create a working grid of $500 \times 500 \mathrm{~m}$, which is close to the coarsest grid size resolution but within the upper and lower recommended grid size.

For the selection of variables of an appropriate GDI, the geological, soil and hydrological diversity indices were included, along with, in the absence of traditional geomorphological maps, four DEM-derived topographical diversity variables. Huaxing (2008) provided an extensive overview of the definition and variables used to measure topographic complexity. He showed that topographic complexity is often used to describe the variability of the terrain surface, either statistically (variance and standard deviations of elevation, arithmetic disparity between the minimum and maximum elevations per unit area, or mean slope) or geometrically (roughness, curvatures, fractal dimension or slope change). Zawada et al. (2010) used the fractal dimension of transects as a proxy for topographic complexity to map the heterogeneous nature of seafloor roughness. In geomorphological research on automated classification of landforms (Drăgut and Eisank 2011, Anders et al. 2013), numerous geometrical variables, such as slope, openness, curvatures and elevation percentile have been used as information layers to decompose elevation models based on topography into coherent landforms. These examples exemplify that many topographic variables may serve as good proxies for topographic complexity, and in our case, topographic diversity. Therefore, the topographical diversity (Tdi) was included in a combination of sums of normalized standard deviations and ranges for both slope and elevation, according to:

$$
\mathrm{Tdi}=0.5 \times(\mathrm{Ssd}+\mathrm{Sr})+0.5 \times(\mathrm{Esd}+\mathrm{Er})
$$

where:

- Ssd - standard deviation of slope diversity,

- Sr - range of slope diversity,

- Esd - standard deviation of elevation diversity,

- Er - range of elevation diversity.

The GDI formula is as follows:

$$
\text { GDI }=\text { Gdi }+ \text { Pdi }+ \text { Hdi }+ \text { Tdi }
$$

where:

- GDI - Geodiversity Index,

- Gdi - Geological diversity,

- Pdi - Pedological diversity,

- Hdi - Hydrology diversity and

- Tdi - Topographical diversity.

\section{Analyses}

Zonal statistics was applied to calculate the variety per pre-defined $500 \times 500 \mathrm{~m}$ grid cell to derive geological, pedological and hydrological sub-indices, which have proven successful in other environments in geodiversity research (Serrano and Ruiz-Flano 2007, Benito-Calvo et al. 2009, Hjort and Luoto 2010, Pereira et al. 2013, Pellitero et al. 2015). The index 
values calculated for the grid cells are summated and ranked into categories to produce a geodiversity map. For each $500 \times 500 \mathrm{~m}$ grid cell, min-max scores were calculated for the geological (1-7) and pedological (1-6) diversities and reclassified into five equal interval classes. For the rasterized hydrological data, a different scoring scheme was used from zero to three, which reflects no surface water (0), the presence of non-perennial surface water (1), the presence of perennial surface water (2) or both (3) in a $500 \times 500 \mathrm{~m}$ grid cell. There were two main reasons for this scoring scheme, the first being that the topographical effect of surface hydrology, such as fluvial incisions and landslides, has already indirectly been included in the diversity of topographical attributes and should therefore have less influence. Secondly, the effects of perennial and non-perennial surface water in Hawaii closely follows the rainy season (NOAA 2017) and therefore contributes differently to landscape processes. Slope angles were calculated using a standard method in ArcMap 10.4 for determining the maximum rate of change in value from a cell to its neighbours. The calculated elevation diversity variables were scaled into five equal

A

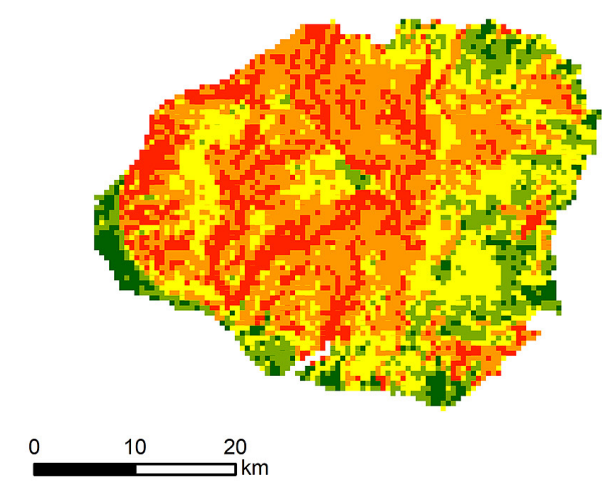

C
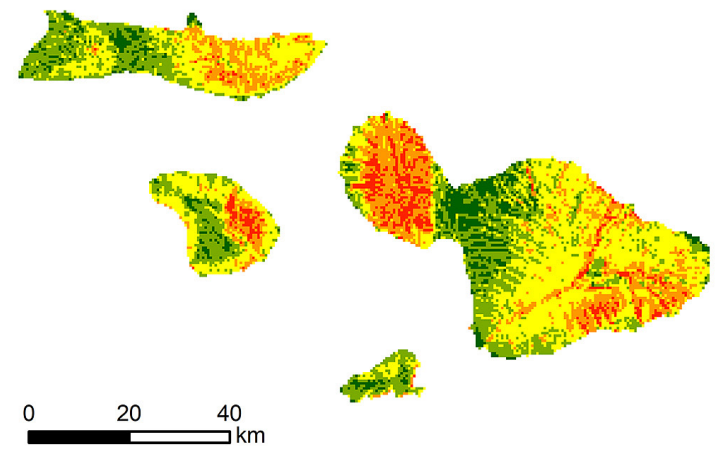

1 - Very low

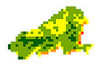

interval classes. Geodiversity scores were calculated using map algebra and then sliced using Jenk's algorithm for natural breaks (Jenk 1967) into very low (1), low (2), medium (3), high (4) and very high (5) geodiversity categories. A correlation matrix was calculated to determine the correlation between each combination of two input variables and to compute areal percentages for each of the five geodiversity categories per island.

\section{Results}

Two trends can be inferred from the spatial distribution of geodiversity patterns, displayed in Fig. 5 using five geodiversity classes. Firstly, the very high and high geodiversity classes increase towards the NE, which coincides with an increase in island age. Secondly, all islands show variations in intra-island geodiversity. This is most likely related to the existence of multiple volcanic centres within the islands, which have undergone asynchronous topographic, soil and
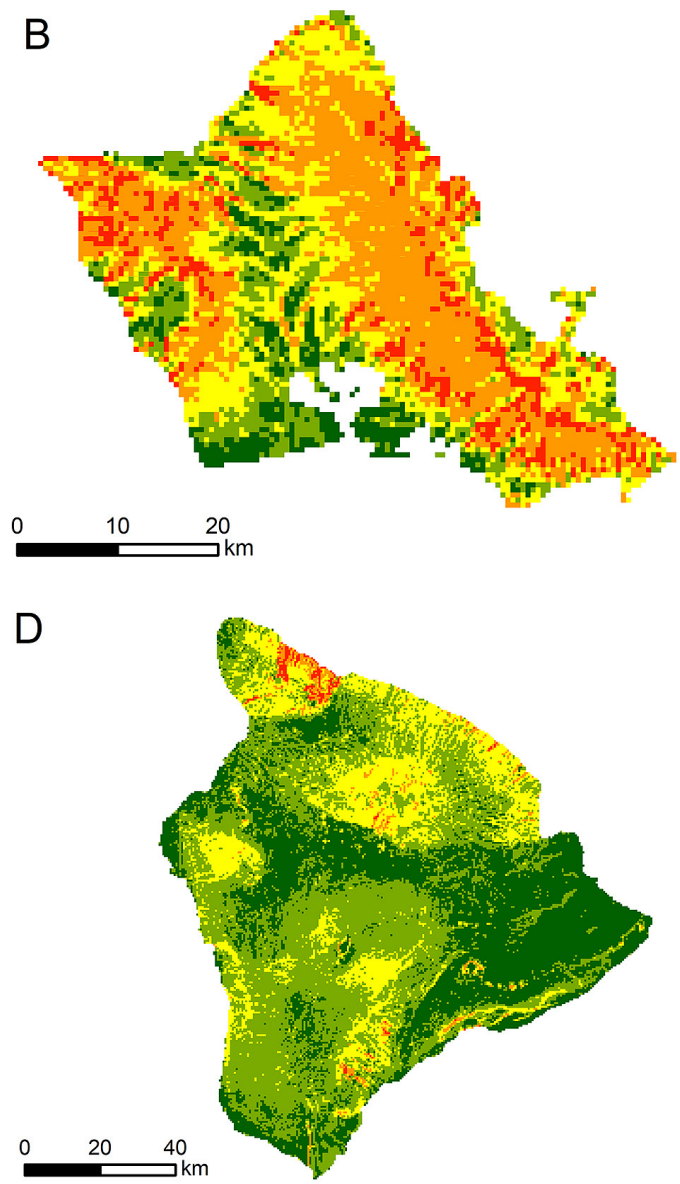

5 - Very high

Fig. 5. Geodiversity map of seven Hawaiian Islands, classified into 5 categories 
Table 2. Geodiversity class in percentages per island, along with correlation coefficients. Island ages are from Eckstut et al. (2011)

\begin{tabular}{lcccccc}
\hline \multirow{2}{*}{ Island } & \multirow{2}{*}{ Age [Ma] } & \multicolumn{5}{c}{ Geodiversity classes [\%] } \\
\cline { 3 - 7 } & & Very High & High & Medium & Low & Very low \\
\hline Hawaii & 0.6 & 0.60 & 1.61 & 20.30 & 43.86 & 33.64 \\
Kahoolawee & 1.8 & 0.51 & 3.59 & 26.07 & 55.63 & 14.21 \\
Maui & 1.0 & 8.55 & 21.09 & 41.99 & 19.78 & 8.59 \\
Lanai & 1.6 & 6.83 & 13.22 & 45.04 & 29.17 & 5.73 \\
Molokai & 2.1 & 1.20 & 17.35 & 40.87 & 31.62 & 8.97 \\
Oahu & 4.0 & 10.21 & 37.52 & 28.40 & 15.07 & 8.67 \\
Kauai & 5.3 & 20.51 & 35.72 & 26.70 & 11.75 & 5.33 \\
\hline Correlation coefficient & & $0.81^{*}$ & $0.84^{*}$ & -0.24 & -0.64 & -0.54 \\
\hline
\end{tabular}

* = significant linear regression coefficient, $p<0.05$.

hydrological development. The areal percentages of the five geodiversity classes per island are listed in Table 3 and support the visual observations of Fig. 5.

In the case of Hawaii, very low and low GD classes dominate $>77 \%$ of the total island area, whereas slightly more than $17 \%$ of surface of the older island of Kauai has a low or very low geodiversity class. A positive and significant correlation was found between island age and the very High (0.81) and high (0.84) GD classes (Table 2). The very low $(-0.54)$, low (-0.64) and medium (-0.24) GD classes have negative and non-significant correlations.

As a general outcome, all topographical variables (slope diversity and elevation) show higher correlations with the GDI than the thematic map layers (Table 3). This suggests that topographic diversity relates mostly to the geodiversity across the islands, and that hydrological, soil and geological diversity contribute to the GDI to a lower extent. The slope and elevation diversity variables have comparably high contributions to the GDI (between 0.75 and 0.84 ). The contribution of geology (0.24) to the GDI is weak, probably because the rock types across the islands are rather similar. The contribution of soil diversity $(0.35)$ to the GDI is substantially lower than all four topographical variables, but cannot be fully ignored as an explanatory variable. Hydrological diversity (0.59) has a higher contribution to the GDI than the geology and soil diversity, but less than the topographic diversity. The mutual correlations of slope and elevation diversity variables are relatively high, while the correlations between thematic diversity variables and topographic variables are generally low.

\section{Discussion}

\section{Interpretation}

The importance of geological diversity within and across all Hawaiian Islands is relatively low. Within the islands, low geological diversity is mainly resulting from the relative homogeneous composition of volcanic rocks, such as basaltic lava flows (Ferrier et al. 2013). Across the islands, this can likely be addressed to the temporal stability of the mantle plume (Sherrod et al. 2007). Overall, geology weakly contributes to the geodiversity dynamics on the Hawaiian Islands. However, in other geological environments components of geological diversity are known to exert a stronger influence on geodiversity of landscapes (Hjort and Luoto 2010, Pereira et al. 2013, Mellelli et al. 2017).

Soil diversity is increasing towards the north-western, older islands, which can be expected, because soil formation depends on parent material, regional climate, organic activity, relief and time (Jenny 1994).

Table 3. Correlation matrix for all input variables and the GDI

\begin{tabular}{|c|c|c|c|c|c|c|c|c|c|}
\hline & \multirow{2}{*}{ GDI } & \multicolumn{2}{|c|}{ Slope diversity } & \multicolumn{2}{|c|}{ Elevation } & \multirow{2}{*}{ Geological diversity } & \multirow{2}{*}{ Soil diversity } & \multirow{2}{*}{ Hydrology diversity } \\
\hline & & & range & std & range & std & & & \\
\hline GDI & & 1 & & & & & & & \\
\hline \multirow{2}{*}{ slope diversity } & range & 0.84 & 1 & & & & & & \\
\hline & std & 0.75 & 0.84 & 1 & & & & & \\
\hline \multirow{2}{*}{ elevation } & range & 0.84 & 1.00 & 0.84 & 1 & & & & \\
\hline & std & 0.80 & 0.67 & 0.56 & 0.67 & 1 & & & \\
\hline \multicolumn{2}{|c|}{ geological diversity } & 0.24 & 0.14 & 0.16 & 0.14 & 0.10 & 1 & & \\
\hline \multicolumn{2}{|l|}{ soil diversity } & 0.35 & 0.18 & 0.21 & 0.18 & 0.10 & 0.20 & 1 & \\
\hline \multicolumn{2}{|c|}{ hydrology diversity } & 0.59 & 0.44 & 0.41 & 0.44 & 0.28 & 0.10 & 0.24 & 1 \\
\hline
\end{tabular}


In addition, soils on islands that are still connected to an active magma plume are rapidly covered by younger deposits, which prohibits soil development and cause low pedodiversity values (Ibáñez and Effland 2011). In addition, the topographic position in the terrain could be important as well, because of its effect on fragmentation of soils in a landscape. For example, on a relatively stable spur thicker soils may develop over time, while active steep slopes or ravines may only host shallow soils. For young volcanic islands, vegetation affects soils through the dominance of pioneer plants, while on aging islands the organic matter production, has more pronounced effects on soil formation (Jefferson et al. 2014). Although debated in some publications, the effects of mega landslides (McMurtry et al. 2004), could be considered, as landslides have certainly stripped the soils and strongly affected the topography of many Hawaiian Islands and, in that way, contributed to setting back soil formation. Finally, anthropogenic-driven soil erosion, triggered by agricultural practices and deforestation of Hawaiian Islands (Crews et al. 1995) could have affected the spatial distribution of current soil orders, but has not been included in this study.

The increase in hydrological diversity in older islands has several reasons. River development on younger islands is hampered by active infill or cover by lava flows (Jefferson et al. 2014) and other volcanic deposits. The initial porosity of most volcanic deposits on the younger islands is relatively high, which suppresses rapid hydrological development. Therefore, the density of rivers and thus hydrology diversity increases towards the northwest. An anomaly is seen on the island of Hawaii, where the elevation has promoted strong orographic-driven precipitation variations, which caused the northern side of the island to become deeply eroded while the southern side generally retained its initial form (Ferrier et al. 2013). This explains the large differences of intra-island hydrological diversity on Hawaii, and part of the variation in geodiversity.

With respect to island ontogeny, this research provides some new perspectives for the interpretation of geodiversity in relation to the stage of island development. Although not quantified, the maximum topographic complexity on islands like Hawaii is postulated to coincide at the maximum growth stage of the volcanic island in the GDM (Whittaker et al. 2008). For the Hawaiian Islands, some alternative trends became apparent from our method, including quantitative topographic variables that are known to reflect terrain complexity (Huaxing 2008). Firstly, topographic diversity contributes most to the geodiversity index and increases with island age for the Hawaiian archipelago, which is in contrast to the theoretical developments of the GDM. Secondly, after the shield volcano is disconnected from the mantle plume at maximum elevations, there is an increase in internal topographical variability, and a decrease in maximum island elevation.

Jefferson et al. (2014) concluded that dissection and degradation of volcanic landscapes typically begins $0.5-2 \mathrm{Ma}$ after eruption of the last lavas that form the main shield volcano. Although they focussed only on the coevolution of hydrology and topography, our findings support the concept that elevation and slope-based variables follow similar temporal trends, as a consequence of the dominance of exogenic over endogenic processes. It should be further noted that in the Hawaiian archipelago islands will eventually submerge, become atolls and even guyots. It should be noted that within the life cycle of the Hawaiian islands sea level changes could have influenced the base levels of the river drainage networks repeatedly. Lower sea levels during glacial periods caused rivers to incise vertically and deepen the valleys, while periods of higher sea level stands relate to phases of fluvial accumulation, especially in the downstream reaches of major rivers. Although not investigated, a loss of topographical diversity towards the atoll and submergence stages is expected, but not necessarily a loss of geodiversity.

\section{Data and methods}

For the first time a temporal component was introduced to quantify patterns of geodiversity dynamics of the Hawaiian Islands. Earlier attempts to include landscape dynamics over time as an explanatory variable only considered theoretical variables, such as topographic complexity in island ontogeny (Warren et al. 2015, Whittaker et al. 2017), soils in pedodiversity (Ibáñez and Effland 2011), or the coevolution of topography and hydrology (Jefferson et al. 2014). It should be kept in mind that our methodological approach is explorative, and open to future methodological improvements. One of the key steps is the selection of an optimal analysis grid size through a critical review of the available data, their quality, scale and the availability of attributes. The guiding principles, suggested by Hengl (2006), proved useful for studying geodiversity dynamics. Refinements of our method could include the use of additional attributes in the available compilation of geological maps (Sherrod et al. 2007). For similar reasons, the use of soil Suborders and/or Great Groups and even chemical composition of the lithology could improve the applicability of the geological sub-index. Similarly, soil chemical variables (USDA 2015) could add to refinement of the soil diversity index. The hydrological diversity now includes perennial, non-perennial and lakes as input, which is thought to co-correlate with topographical variables over time (Jefferson et al. 2014), and is, in our study, supported by a correlation 
of 0.44 between the hydrology diversity and slope diversity (Table 3). A general improvement could be the inclusion of geomorphological maps with consistent legends, but these were not freely available or lacking. This is not the case for the soil and geological maps, which conform to well-known and consistently used classification systems for soils, e.g. that of the USDA (2015) or the World Soil Reference Base (IUSS 2007), which are interchangeable to a large degree. Systematic litho- and chronostratigraphic geological classification systems exist as well, in which consistent rock classification methods have been embedded. It should be kept in mind that the freely available thematic map data was made by experienced earth scientists largely in a pre-digital era, without geodiversity as a focus. Information on thematic map accuracies is, in most cases, lacking, which also hampers a reliable assessment of the geodiversity assessment. However, the inclusion of transparent and transferable quantitative DEM-derived variables promotes comparison between areas of interest (Anders et al. 2013). For example, the standard deviation of slope angle and elevation were found to be a good predictor of geodiversity in this study, which fits well with similar findings of Hjort and Luoto (2012) for three different study sites. For this study we can confirm their findings that variables describing high potential energy and topographical heterogeneity are suitable to predict geodiversity.

\section{Conclusions}

From this study some interesting conclusions can be made on geodiversity dynamics using the workflow proposed in this study. Firstly, it is concluded that very high and high geodiversity classes positively correlate to the age of islands in the Hawaiian archipelago. Secondly, geodiversity is strongly correlated to the range and standard deviation of elevation, the range and standard elevation of slope, and to lesser extents, to hydrological, soil and geological diversity. Thirdly, all islands show variations in intra-island geodiversity, which is related to the presence of different volcanic centres, which have undergone non-synchronous topographic, soil and hydrological developments. Finally, it is noted that after shield volcanoes become disconnected from their magma source at maximum island elevation, their internal topographical variability increases over time in the case of the Hawaiian islands, which is not fully underpinned in the biogeographical general dynamic theory, in which the oldest islands of an archipelago are assumed to have the lowest degree of topographic variability.

\section{Acknowledgments}

Funding was awarded by the Theoretical and Computational Ecology (TCE) group of the Institute for Biodiversity and Ecosystem Dynamics (IBED) of the University of Amsterdam (UvA). The GIS-studio (www.GIS-studio.nl) of the University of Amsterdam is thanked for computational support. Ms Stacy Shinneman of the Computational and Theoretical Ecology department is thanked for correcting language and style.

\section{References}

Anders N.S., Seijmonsbergen A.C., Bouten W., 2013. Geomorphological change detection using object-based feature extraction from multi-temporal LiDAR Data. IEEE Geoscience and Remote Sensing 10: 1587-1591. DOI: 10.1109/LGRS.2013.2262317.

Araujo A.M., Pereira D.I., 2017. A new methodological contribution for the geodiversity assessment: applicability to Ceará State (Brazil). Geoheritage. DOI: 10.1007/s12371-017-0250-3.

Bailey J., Boyd D. S., Hjort J., Lavers C.P., Field R., 2017. Modelling native and alien vascular plant species richness: At which scales is geodiversity most relevant? Global Ecology and Macroecology: 1-17. DOI: 10.1111/geb.12574.

Benito-Calvo A., Perez-Gonzalez A., Magri O., Meza P., 2009. Assessing regional geodiversity: the Iberian Peninsula. Earth Surface Processes and Landforms 34: 1433-1445.

Burek C.V., Prosser C.D., 2008. The history of geoconservation: an introduction. In: C.V.Burek, C.D.Prosser (eds), The history of geoconservation, Geological Society, London, Special Publications 300: 1-5.

Clague D.A., Dalrymple G.B., 1989. Tectonics, geochronology, and origin of the Hawaiian-Emperor chain. The geology of North America: the Eastern Pacific Ocean and Hawai'i. The Geological Society of America, Boulder, CO, USA: 188-217.

Crews T.E., Kitayama K., Fownes J.H., Riley R.H., Herbert D.A., Mueller-Dombois D., Vitousek P.M., 1995. Changes in phosphorous Fractions and Ecosystem Dynamics across a Long Chronosequence in Hawaii. Ecology 76: 1407-1424. DOI: $10.2307 / 1938144$.

Darwin C. R., 1842. The structure and distribution of coral reefs. Being the first part of the geology of the voyage of the Beagle, under the command of Capt. Fitzroy, R.N. during the years 1832 to 1836. London: Smith Elder and Co, 65, Cornhill.

Drăgut L., Eisank C., 2011. Automated classification of topography from SRTM data using object-based image analysis. In: T.Hengl, I.S.Evans, J.P.Wilson, M.Gould (eds), Geomorphometry 2011, 7-9 September 2011, Redlands, CA, USA, 113-116.

Eckstut M.E., McMahan C.D., Crother B.I., Ancheta J.M., McLennan D.A., Brooks D.R., 2011. PACT in practice: comparative historical biogeographic patterns and species-area relationships of the Greater Antillean and Hawaiian Island terrestrial biotas. Global Ecology and Biogeography 20: 545-557. DOI: 10.1111/j.1466-8238.2010.00626.x.

Ferrier K.L., Taylor Perron J., Mukhopadhyay S., Rosener M., Stock J., Slosberg M., Huppert K.L., 2013. Covariation of climate and long-term erosion rates across a steep rainfall gradient on the Hawaiian island of Kaua'i. Geological Society of American Bulletin 125: 1146-1163. DOI: 10.1130/B30726.1.

Gray J.M., 2013. Geodiversity: valuing and conserving abiotic nature. 2nd Edition, John Wiley, Chichester.

Greenberg H., 2007. Hawaii 10 m DEMs. United States Geological Survey, Seattle. 
Hengl T., 2006. Finding the right pixel size. Computers \& Geosciences 32: 1283-1298. DOI: 10.1016/j.cageo.2005.11.008.

Hjort J., Luoto M., 2010. Geodiversity of high-latitude landscapes in northern Finland. Geomorphology 115: 109-116. DOI: 10.1016/j.geomorph.2009.09.039.

Hjort J., Luoto M., 2012. Can geodiversity be predicted from space? Geomorphology 153: 74-80. DOI: 10.1016/j.geomorph.2012.02.010.

Hjort J., Gordon J.E., Gray M., Hunter M.L. Jr., 2015. Why geodiversity matters in nature's stage. Conservation Biology 29(3): 630-639. DOI: 10.1111/cobi.12510.

Huaxing L., 2008. Modelling Terrain Complexity. In: Q.Zhou, B.Lees, G.Tang (eds), Advances in Digital Terrain Analysis. Lecture Notes in Geoinformation and Cartography. Springer, Berlin, Heidelberg: 159-176.

Ibáñez J.J., Effland W.R., 2011. Toward a theory of island pedogeography: Testing the driving forces for pedological assemblages in archipelagos of different origins. Geomorphology 135(3-4): 215-223. DOI: 10.1016/j.geomorph.2011.02.010.

IUSS Working Group WRB., 2007. World reference base for soil resources 2006, first update 2007. World Soil Resources Reports No. 103. FAO, Rome. Online: www.fao.org/fileadmin/ templates/nr/images/resources/pdf_documents/wrb2007_red. pdf - 02.02.2018

Jefferson A.J., Ferrier K.L., Perron J.T., Ramalho R., 2014. Controls on the hydrological and topographic evolution of shield volcanoes and volcanic ocean islands. The Galapagos: A Natural Laboratory for the Earth Sciences 204: 185-213.

Jenks G.F., 1967. The Data Model Concept in Statistical Mapping. International Yearbook of Cartography 7: 186-190.

Jenny H., 1994. Factors of Soil Formation. A System of Quantitative Pedology. New York: Dover Press. Reprint, Online: soilandhealth.org/wp-content/uploads/01aglibrary/010159.Jenny. pdf -2.02 .2018 .

Knight J., Grab S., Esterhuysen A.B., 2015. Geoheritage and geotourism in South Africa. In: S.Grab, J.Knight (eds), Landscapes and Landforms of South Africa, World Geomorphological Landscapes, Springer International Publishing Switzerland. DOI: 10.1007/978-3-319-03560-4_19.

MacArthur R.H., Wilson E.O., 1967. The theory of island biogeography. Princeton University Press, Princeton, NJ.

McMurtry G.M., Watts P., Fryer G., Smith J.R., Imamura F., 2014. Giant landslides, mega-tsunamis, and paleo-sea level in the Hawaiian Islands. Marine Geology 203(3-4): 219-233. DOI: 10.1016/S0025-3227(03)00306-2.

Melelli, L., Vergari F., Liucci L., Del Monte M. (2017). Geomorphodiversity index: Quantifying the diversity of landforms and physical landscape. Science of Total Environment, 584-585, pp. 701-714.

Najwer A., Borysiak J., Gudowicz J., Mazurek M., Zwoliński Zb., 2016. Geodiversity and biodiversity of the postglacial landscape (Dębnica river catchment, Poland). Quaestiones Geographicae 35(1): 5-28. DOI: 10.1515/ quageo-2016-0001.

Newsome D., Dowling R., 2017. Geoheritage and Geotourism. In: E.Reynard, J.Brilha (eds), Geoheritage, assessment, protection and management. Elsevier: 305-321.

NOAA [National Oceanic and Atmospheric Administration], 2017. National Weather Service. Climate of Hawai'i. Online: www. prh.noaa.gov/hnl/pages/climate summary.php - 2.02.2018.

NPS \{National Park Service], 2017. National Park Service Hawaii. Online: www.nps.gov/state/hi/index.htm - 2.02.2018.

Pellitero R., Gonzalez-Amuchastegui M.J., Ruiz-Flaño P., Serrano E., 2011. Geodiversity and geomorphosites assessment applied to a natural protected area: the Ebro and Rudron gorges Natural Park (Spain). Geoheritage 3: 163-174. DOI: 10.1007/s12371010-0022-9.

Pellitero R., Manosso F.C., Serrano E., 2015. Mid- and large-scale geodiversity calculation in Fuentes Carrionas (NW Spain) and Serra do Cadeado (Paranná, Brazil): methodology and application for land management. Geografiska Annaler: Series A, Physical Geograpgy 97(2): 219-235. DOI: 10.1111/geoa.12057.
Pereira D.I., Pereira P., Brilha J., Santos L., 2013. Geodiversity assessment of Paraná State (Brazil): an innovative approach Environmental Management 52(3): 541-552. DOI: 10.1007/ s00267-013-0100-2.

Ribe N.M., Christensen U.R., 1999. The dynamical origin of Hawaiian volcanism. Earth and Planetary Science Letters 171: 517-531.

Rijsdijk K.F., Hengl T., Norder S.J., Otto R., Emerson B.C., Ávila S.P., López H., van Loon E.E., Tjørve E., Fernández-Palacios J.M., 2014. Quantifying surface-area changes of volcanic islands driven by Pleistocene sea-level cycles: biogeographical implications for the Macaronesian archipelagos. Journal of Biogeography 41(7): 1242-1254. DOI: 10.1111/jbi.12336.

Roderick G.K., Croucher P.J., Vandergast A.G., Gillespie R.G., 2012. Species differentiation on a dynamic landscape: shifts in metapopulation genetic structure using the chronology of the Hawaiian archipelago. Evolutionary Biology 39(2): 192-206.

Seijmonsbergen A.C., De Jong M.G.G., de Graaff L.W.S, Anders N.S., 2014. Geodiversität von Vorarlberg und Liechtenstein, Geodiversity of Vorarlberg and Liechtenstein, Haupt Verlag, Zürich.

Serrano E., Ruiz-Flaño P., 2007. Geodiversity: a theoretical and applied concept. Geographica Helvetica 62 (3): 140-147.

Sherrod D.R., Sinton J.M., Watkins S.E., Brunt K.M., 2007. Geologic map of the State of Hawai i. U.S. Geological Survey, California. U.S. Geological Survey Open-File Report 2007-1089. Online: pubs.usgs.gov/of/2007/1089/-2.02.2018.

Silva J., Rodrigues C., Pereira D., 2015. Mapping and analysis of geodiversity indices in the Xingu River basin, Amazonia, Brazil. Geoheritage 7: 337-350. DOI: 10.1007/s12371-014-0134-8.

Stuessy T.F., 2007. Evolution of specific and genetic diversity during ontogeny of island floras: the importance of understanding process for interpreting island biogeographic patterns. In: M.C.Ebach, R.S.Tangney (eds), Biogeography in a changing world. Boca Raton, FL, CRC Press: 117-133.

Tukiainen H., Bailey J.J., Field R., Kangas K., Hjort J., 2016. Combining geodiversity with climate and topography to account for threatened species richness. Conservation Biology 31(2): 364 375. DOI: 10.1111/cobi.12799.

USDA [United States Department of Agriculture], 2015. Soil Survey Geographic (SSURGO) database for islands of Hawaii area. SSURGO, Texas.

USGS [United States Geological Survey], 2010. National Hydrography Dataset (NHD). National Geospatial Technical Operations Center.

Warren B.H., Simberloff D., Ricklefs R.E., Aguilée R., Condamine F.L., Gravel D., Morlon H., Rosindell J., Casquet J., Conti E., Cornuault J., Fernández-Palacios J.M., Hengl T., Norder S.J., Rijsdijk K.F., Sanmartín I., Strasberg D., Triantis K.A., Valente L.M., Whittaker R.J., Gillespie R.G., Emmerson B.C., Thébaud C., 2015. Islands as model systems in ecology and evolution: prospects fifty years after MacArthur-Wilson. Ecology Letters 18(2): 200-217. DOI: 10.1111/ele.12398.

Whittaker R.J., Triantis K.A., Ladle R.J., 2008. A general dynamic theory of oceanic island biogeography. Journal of Biogeography 35(6): 977-994. DOI: 10.1111/j.1365-2699.2008.01892.x.

Whittaker R.J., Fernández-Palacios J.M., Matthews T.J., Borregaard M.K., Triantis K.A., 2017. Island biogeography: Taking the long view of nature's laboratories. Science 357(6354). DOI: org/10.1126/science.aam8326.

Wilson J.T., 1963. A possible origin of the Hawaiian Islands. Canadian Journal of Physics 41(6): 863-870.

Zawada D.G., Piniak G.A., Hearn C.J., 2010. Topographic complexity and roughness of a tropical benthic seascape. Geophysical Research Letters 37: L14604. DOI: 10.1029/2010GL043789.

Ziegler A.C., 2002. Hawaiian natural history, ecology, and evolution. University of Hawaii Press, Honolulu, HI.

Zwoliński Zb., Stachowiak J., 2012. Geodiversity map of the Tatra National Park for geotourism. Quaestiones Geographicae 31(1): 99-107. DOI: 10.2478/v10117-012-0012-x.

Zwoliński Zb., Najwer A., Giardano M., 2017. Methods for assessing geodiversity. In: E.Reynard, J.Brilha (eds), Geoheritage - assessment, protection and management, Elsevier: 27-51. 